\title{
Characterizing Resistance to Phakopsora pachyrhizi in Soybean
}

M. R. Miles, United States Department of Agriculture-Agricultural Research Service (USDA-ARS), Urbana, IL 61801; M. R. Bonde, S. E. Nester, D. K. Berner, and R. D. Frederick, USDA-ARS, Foreign Disease-Weed Science Research Unit, Ft. Detrick, MD 21702; and G. L. Hartman, USDA-ARS and Department of Crop Sciences, University of Illinois, Urbana 61801

\begin{abstract}
Miles, M. R., Bonde, M. R., Nester, S. E., Berner, D. K., Frederick, R. D., and Hartman, G. L. 2011. Characterizing resistance to Phakopsora pachyrhizi in soybean. Plant Dis. 95:577-581.

Resistance in soybean to Phakopsora pachyrhizi, the cause of soybean rust, is characterized by either reddish-brown (RB) lesions or an immune response. The RB type of resistance can be incomplete, as evidenced by the presence of sporulating uredinia within lesions. Susceptibility, on the other hand, is exemplified by tan-colored (TAN) lesions, and can be expressed in gradations of susceptibility or partial resistance that are less well defined. This study evaluated traits associated with incomplete or partial resistance to P. pachyrhizi in soybean by comparing 34 soybean accessions inoculated with four $P$. pachyrhizi isolates. Six accessions produced RB lesions to all four isolates, while 19 accessions produced TAN lesions, including plant introduction (PI) 200492 (Rpp1) and the susceptible check 'Williams'. Williams had

values and area under the sporulating uredinia progress curve (AUSUPC) values, while eight accessions had lower AUSUPC values. Of the known sources of single-gene resistance, only PI 230970 (Rpp2), PI 459025B (Rpp4), and PI 594538A (Rpplb) had lower AUDPC and AUSUPC values than Williams. PI 594538A and PI 561356 had RB lesions and had the lowest AUDPC and AUSUPC values. Of the known sources of single-gene resistance, only PI 230970 (Rpp2) and PI 594538A (Rpp1b) produced fewer and smaller-diameter uredinia than Williams. This study characterized reactions to $P$. pachyrhizi in 34 accessions based on lesion type and sporulation, and defined incomplete resistance and partial resistance in the soybean- $P$. pachyrhizi interaction.
\end{abstract} among the largest area under the disease progress curve (AUDPC)
Soybean rust (Phakopsora pachyrhizi Syd. \& P. Syd.) has been a major disease limiting soybean (Glycine $\max$ (L.) Merr.) production in the tropical and subtropical areas of Africa, Asia, and South America, where yield losses from 10 to $80 \%$ have been reported $(8,13,31)$. Fungicides are effective in managing soybean rust; however, their application increases production costs $(19,20)$. The development of commercial soybean cultivars with resistance to $P$. pachyrhizi may be one of the most cost-effective ways to reduce yield loss $(7,18)$, although no commercial soybean cultivars with rust resistance have been marketed in the United States.

Specific resistance to $P$. pachyrhizi is known, and seven dominant genes controlling pathotype-specific resistance to soybean rust have been identified at five loci $(3-5,9-11,15,26)$. These known genes conferred resistance to some $P$. pachyrhizi isolates but were ineffective when challenged with other isolates $(1,22,23)$. The three plant responses that have been shown to be associated with single dominant genes for soybean rust resistance are (i) an immune response (IR); (ii) reddish-brown (RB) lesions, or incomplete resistance; and (iii) the susceptible tan (TAN) lesions (2). The IR has only been reported with Rppl, and only when inoculated with specific isolates $(1,22,23)$. For both the RB and TAN lesion types, sporulation of uredinia has been reported to vary (1), although the genetics of inheritance of this trait have not been described. For the $\mathrm{RB}$ reaction type, three subclasses ranging from less to more sporulation have been identified and, for the TAN reaction type,

Corresponding author: G. L. Hartman, E-mail: ghartman@illinois.edu

Trade and manufacturers' names are necessary to report factually on available data; however, the USDA neither guarantees nor warrants the standard of the product, and the use of the name by USDA implies no approval of the product to the exclusion of others that may also be suitable.

Accepted for publication 13 January 2011.

doi:10.1094/PDIS-06-10-0450

This article is in the public domain and not copyrightable. It may be freely reprinted with customary crediting of the source. The American Phytopathological Society, 2011. two subclasses characterized by "few" or "many" uredinia per lesion have been identified (2).

In greenhouse inoculation studies, host-pathogen combinations that resulted in $\mathrm{RB}$ lesions tended to exhibit longer latent periods and fewer and smaller uredinia than interactions producing susceptible TAN lesions $(1,2,14)$. It also was shown that RB lesions had variable color from light to dark brown, and often were larger than TAN lesions (1). These observations suggest that lesion color by itself is not a reliable means to rate resistance or susceptibility.

Incomplete resistance has been defined as a resistant reaction that allows for some growth or reproduction of the pathogen $(21,24)$. For incomplete resistance to soybean rust, we define this as an RB reaction type. Partial resistance can be defined as a susceptible reaction with reduced fungal colonization or sporulation compared with another fully susceptible type (21). For the susceptible reaction to soybean rust, this would be the TAN reaction type. The objective of this research was to further refine the definitions of incomplete and partial resistance in the soybean-P. pachyrhizi interaction by characterizing the response in 34 soybean accessions inoculated individually with four $P$. pachyrhizi isolates. In addition to lesion type and severity, the number of sporulating uredinia, number of uredinia per lesion, and uredinial diameter were evaluated, as well as differences in relative sporulation levels of RB lesions compared with a susceptible cultivar with TAN lesions.

\section{Materials and Methods}

Isolates and soybean accessions. The four $P$. pachyrhizi isolates used in this study were Brazil 01-1 (BZ01-1), Paraguay 01-2 (PG01-2), Thailand 01-1 (TH01-1), and Zimbabwe 01-1 (ZM011). They were collected in 2001 and were the same isolates previously used in seedling evaluations of the United States Department of Agriculture (USDA) soybean germplasm collection (17). The four $P$. pachyrhizi isolates were obtained by increasing urediniospores from an individual soybean leaf from each of the four field collections. All increases were made on the susceptible soybean 'Williams', and urediniospores were propagated, harvested, and stored in liquid nitrogen as previously described $(1,17)$. Prior to inoculation, urediniospores were removed from liquid nitrogen 
storage, heat-shocked at $40^{\circ} \mathrm{C}$ for $5 \mathrm{~min}$, and hydrated by incubating overnight in a small plastic weigh boat over water in an enclosed petri plate. Inoculum was prepared by adding urediniospores to distilled water containing $0.01 \%$ Tween 20 ( $\mathrm{vol} / \mathrm{vol})$, vigorously mixing in a beaker with a glass rod, and filtering the spore suspension through a nylon screen with $53-\mu \mathrm{m}$ pores. Urediniospores were quantified using a hemacytometer and diluted in distilled water to a final concentration of $6 \times 10^{4}$ spores $/ \mathrm{ml}$ for inoculation. The germination rates were obtained for each isolate on each run of the experiment by spraying inoculum onto the surface of water agar (WA) in a petri plate as plants were inoculated. The plate was placed in the dew chamber overnight at 20 to $22^{\circ} \mathrm{C}$, and, the next morning, the number of germinating urediniospores per 100 urediniospores was determined at $\times 100$ magnification.

The 33 soybean accessions were obtained from the USDA Soybean Germplasm Collection Center at Urbana, IL, except for G7955 ('Ankur'), the source of the Rpp3 gene, which was obtained from the Asian Vegetable Research Development Center, Genetic Resources and Seed Unit, Shanhua, Taiwan and increased in the greenhouse at Urbana, IL. Also included in this study were plant introduction (PI) 200492 (Rppl), PI 230970 (Rpp2), and PI 4590025B (Rpp4), as well as PI 547875 (Williams isoline with Rppl) and Williams 82. All other accessions were selected based on their rank as having low soybean rust severity among 6,000 accessions previously screened and included both RB and TAN lesion types (17). The experimental design was a split plot, with isolates as the main plot and accessions as the subplots. The accessions were arranged as four randomized replicates for each isolate, and a single trifoliolate from a single plant per accession was evaluated in each replicate. Due to space and time limitations, two isolates were inoculated on a given day with a minimum 2week interval between inoculations. The experiment was conducted in the USDA Agricultural Research Service Foreign Disease-Weed Science Research Unit (FDWSRU) Biosafety Level 3 Plant Pathogen containment greenhouses under controlled inoculation conditions (16) and repeated once.

Two seeds of each accession were planted in a single cell of a flat $(27$ by $52 \mathrm{~cm}$ ) containing 6-by-12 cells filled with Sunshine LC1 mix (Sun-Grow Horticulture Products, Belleview, WA). Cells on the outside edge of the flats were planted to either 'Ina' or Williams, both susceptible. After emergence, plants were thinned to one plant per cell and inoculated 16 to 21 days after planting, when the first trifoliolate was fully expanded. Using an atomizer, each flat of plants was sprayed several times in succession with $40 \mathrm{ml}$ of the spore suspension at $138 \mathrm{kPa}$ until runoff, and then placed overnight in a dew chamber at 20 to $22^{\circ} \mathrm{C}$. Plants were removed from the dew chamber and placed in the greenhouse at 20 to $25^{\circ} \mathrm{C}$ under a 16-h photoperiod, and watered from below. Supplemental light was provided by 1,000-W Metalarc lights (Sylvania, Danvers, MA), spaced $0.6 \mathrm{~m}$ apart, $1.2 \mathrm{~m}$ above the bench.

Rust assessments on leaves. Lesion type, rust severity, and number of sporulating uredinia were assessed visually on the first trifoliolate at $\times 1$ and $\times 15$ magnification at $8,10,13,15$, and 17 days after inoculation (DAI).

Reaction type was recorded as TAN, RB, or IR. An IR was given only when no visible lesions were observed. When both TAN and $\mathrm{RB}$ lesions were present on the same trifoliolate, the lesion type was recorded as a mixed (MX) reaction.

Rust severity was assessed on a scale of 1 to 5 based on percentage of leaf area affected, where $1=$ no visible lesions, $2=0.1$ to $2.5 \%$ leaf area affected, $3=2.6$ to $10 \%$ of leaf area affected, $4=$ 10.1 to $30 \%$ of leaf area affected, and $5=$ over $30 \%$ of leaf area affected. Area under the disease progress curve (AUDPC) was calculated based on the five assessment dates (25).

The number of sporulating uredinia was counted on the center leaflet of each trifoliolate in the area within two 1.2-cm-diameter circles, spaced $3 \mathrm{~cm}$ apart. A cellophane template, on which the circles were cut out, was positioned so that the circles were on either side of the midrib at the widest part of the leaflet. To ensure that the template was repositioned over the same area of the leaflet on subsequent evaluation dates, two marks were made on the leaflet with a black permanent ink pen using positioning notches on the template. The number of sporulating uredinia from both circles was combined, and the data used to calculate area under the sporulating uredinia progress curve (AUSUPC) based on the five assessment dates (25).

Sporulation levels within RB lesions at 15 DAI were compared with sporulation on Williams. The level of sporulation was based on a pretransformed scale where $0=$ no sporulation, $1=1$ to $10 \%$, $2=11$ to $35 \%, 3=36$ to $65 \%, 4=66$ to $90 \%$, and $5=91$ to $100 \%$ of the fully sporulating lesions on Williams.

Number of uredinia per lesion and their diameters on fixed leaves. At 17 DAI, trifoliolates were excised and the center leaflet from each trifoliolate was placed in a solution of absolute ethanol/acetic acid (3:1, vol/vol) for $16 \mathrm{~h}$ to fix and remove plant pigments from the tissue. The leaflets were transferred to lactophenol for at least $24 \mathrm{~h}$ to further clear and make the tissue translucent, and then stained in $0.1 \%$ cotton blue in lactophenol for $24 \mathrm{~h}$. The stained leaflets were rinsed in lactophenol, placed in an inverted petri plate top, covered with a thin layer of lactophenol, and sealed with a noninverted petri plate bottom nested in the top (1). Stained leaflets were examined microscopically at $\times 10$ and $\times 90$, and measurements of uredinia were made with an ocular micrometer. The number of uredinia per lesion was counted for 25 lesions, and the uredinial diameters of 25 isolated uredinia were measured from two replicate leaflets. This was done for the first run of the experiment.

Statistical analyses. Data from the two runs of the experiment were tested for homogeneity of error variance before pooling data. Pooled data analyses were performed with JMP (version 7; SAS Institute, Cary, NC). In this analysis, accessions, isolates, and their interaction were considered fixed effects, and runs, replications, and the overall interaction were random effects. Differences in least squares means were generated with "lsmeans" statements, and were separated using Fisher's protected least significant difference test, where $\alpha=0.05$, for each analysis. PROC CORR procedure was used to compute Pearson's correlation coefficients for pairs of variables.

The relative sporulation levels within RB lesions were analyzed using data from the six accessions that produced RB lesions when inoculated with all isolates. Sporulation levels within RB lesions were evaluated using a pretransformed 0-to-5 scale. Mean RB sporulation levels were compared using a mixed model in JMP. Fisher's protected least significant difference test was used to compare accession means, where $\alpha=0.05$.

\section{Results}

Reaction type. Six accessions produced RB lesions when inoculated with each of the four P. pachyrhizi isolates (Table 1): PI 081765, PI 230970 (Rpp2), PI 423972, PI 459025B (Rpp4), PI 561356 , and PI 594538A (Rpplb). Nineteen accessions, including the susceptible check Williams, PI 200492 (Rppl), and PI 547875 (Rppl), produced TAN lesions to all four isolates (Table 1). Ten accessions produced MX reactions when inoculated with isolates BZ01-1, PG01-2, TH01-1, and ZM01-1 (Table 1): four produced MX, MX, TAN, and TAN; four produced MX, TAN, TAN, and TAN; one produced TAN, MX, TAN, and TAN; and one produced $\mathrm{MX}, \mathrm{MX}, \mathrm{RB}$, and RB.

Rust severity. The mean soybean rust severity increased from 8 to $17 \mathrm{DAI}$, with an average severity of $2.4 \pm 0.02$ at $8 \mathrm{DAI}$ and 3.0 \pm 0.02 at 17 DAI. AUDPC data from the two runs were combined based on nonsignificant homogeneity of variance. There was no isolate-accession interaction for AUDPC but isolate and accession alone were significant (Table 2). AUDPC was highest for ZM01-1 (25.7), followed by PG01-2 (25.1), which did not differ from ZM01-1 or TH01-1 (24.4); BZ01-1 (22.3) differed $(P \leq 0.05)$ from all other isolates. The differences in severity were not associated with urediniospore germination rates on WA plates. BZ01-1, with the lowest AUDPC value, was among the isolates with the highest urediniospore germination. The mean urediniospore germination 
rates were 72, 62, 53, and 59\% for BZ01-1, PG01-2, TH01-1, and ZM01-1, respectively, when averaged across runs. The AUDPC values among accessions ranged from 21 to 27 (Table 1). Williams had one of the highest values, while 16 accessions were lower $(P \leq$ $0.05)$ than Williams. Of the known sources of single-gene resistance, only PI 547875 (Rppl), G 7955 (Rpp3), and PI 594538A $(R p p l b)$ had lower $(P \leq 0.05)$ AUDPC values than Williams.

Sporulating uredinia. The mean numbers of sporulating uredinia increased from 8 to $17 \mathrm{DAI}$, with an average of $0.1 \pm 0.03$ at 8 , $10.4 \pm 0.38$ at $10,19.6 \pm 0.58$ at $12,30.5 \pm 0.92$ at 15 , and $35.9 \pm$ 1.00 at 17 DAI. AUSUPC data from the two runs were combined based on nonsignificant homogeneity of variance. There was no isolate-accession interaction for AUSUPC but isolate and accession alone were significant (Table 2). The AUSUPC value was highest for ZM01-1 (218) and PG01-2 (193) isolates, which dif-

Table 1. Lesion type, area under disease progress curve (AUDPC), and area under sporulating uredinia progress curve (AUSUPC) for 34 soybean accessions inoculated with four isolates of Phakopsora pachyrhizi under greenhouse conditions ${ }^{\mathrm{r}}$

\begin{tabular}{|c|c|c|c|}
\hline Accession & Lesion type & AUDPC & AUSUPC \\
\hline PI 423972 & RB & $27 \mathrm{~A}$ & $199 \mathrm{~A}-\mathrm{G}$ \\
\hline Williams & TAN & $27 \mathrm{~A}-\mathrm{B}$ & $223 \mathrm{~A}-\mathrm{D}$ \\
\hline PI 081765 & $\mathrm{RB}^{\mathrm{v}}$ & $26 \mathrm{~A}-\mathrm{D}$ & $163 \mathrm{~B}-\mathrm{H}$ \\
\hline PI 084674 & TAN $^{w}$ & $26 \mathrm{~A}-\mathrm{C}$ & $241 \mathrm{~A}$ \\
\hline PI 189402 & TAN & $26 \mathrm{~A}-\mathrm{F}$ & $225 \mathrm{~A}-\mathrm{C}$ \\
\hline PI 200492 (Rppl) & TAN & $26 \mathrm{~A}-\mathrm{C}$ & $235 \mathrm{~A}$ \\
\hline PI 417089A & TAN $^{\mathrm{V}}$ & $26 \mathrm{~A}-\mathrm{D}$ & $191 \mathrm{~A}-\mathrm{G}$ \\
\hline PI 438480 & TAN & $26 \mathrm{~A}-\mathrm{E}$ & $233 \mathrm{~A}-\mathrm{B}$ \\
\hline PI 467323A & TAN $^{v}$ & $26 \mathrm{~A}-\mathrm{D}$ & $208 \mathrm{~A}-\mathrm{F}$ \\
\hline PI 196529 & TAN $^{x}$ & $25 \mathrm{~A}-\mathrm{H}$ & $182 \mathrm{~A}-\mathrm{G}$ \\
\hline PI 206258 & TAN & $25 \mathrm{~B}-\mathrm{I}$ & $175 \mathrm{~A}-\mathrm{H}$ \\
\hline PI 230970 (Rpp2) & $\mathrm{RB}$ & $25 \mathrm{~A}-\mathrm{G}$ & $78 \mathrm{~J}-\mathrm{L}$ \\
\hline PI 417560 & TAN & $25 \mathrm{~A}-\mathrm{H}$ & $186 \mathrm{~A}-\mathrm{G}$ \\
\hline PI 459025B (Rpp4) & RB & $25 \mathrm{~A}-\mathrm{H}$ & $110 \mathrm{H}-\mathrm{I}$ \\
\hline PI 548484 & TAN & $25 \mathrm{~A}-\mathrm{F}$ & $210 \mathrm{~A}-\mathrm{F}$ \\
\hline PI 561287B & TAN & $25 \mathrm{~A}-\mathrm{G}$ & $195 \mathrm{~A}-\mathrm{G}$ \\
\hline PI 084668 & TAN $^{v}$ & $24 \mathrm{~B}-\mathrm{J}$ & $171 \mathrm{~A}-\mathrm{H}$ \\
\hline PI 091144 & TAN & $24 \mathrm{E}-\mathrm{L}$ & $170 \mathrm{~A}-\mathrm{H}$ \\
\hline PI 164885 & TAN $^{\mathrm{x}}$ & $24 \mathrm{C}-\mathrm{K}$ & $190 \mathrm{~A}-\mathrm{G}$ \\
\hline PI 196528 & TAN & $24 \mathrm{C}-\mathrm{K}$ & $215 \mathrm{~A}-\mathrm{E}$ \\
\hline PI 417012 & TAN & $24 \mathrm{~B}-\mathrm{J}$ & 214 A-E \\
\hline PI 424456 & TAN $^{x}$ & $24 \mathrm{D}-\mathrm{L}$ & $147 \mathrm{E}-\mathrm{I}$ \\
\hline PI 437241 & TAN & $24 \mathrm{C}-\mathrm{K}$ & $194 \mathrm{~A}-\mathrm{G}$ \\
\hline PI 507716 & TAN $^{\mathrm{y}}$ & $24 \mathrm{D}-\mathrm{K}$ & $202 \mathrm{~A}-\mathrm{G}$ \\
\hline PI 508269 & TAN & $24 \mathrm{E}-\mathrm{L}$ & $185 \mathrm{~A}-\mathrm{G}$ \\
\hline PI $547875(R p p 1)$ & TAN & $24 \mathrm{E}-\mathrm{L}$ & $173 \mathrm{~A}-\mathrm{H}$ \\
\hline G $7955(R p p 3)$ & TAN $^{x}$ & $23 \mathrm{H}-\mathrm{L}$ & $157 \mathrm{C}-\mathrm{H}$ \\
\hline PI 427241 & TAN & $23 \mathrm{G}-\mathrm{L}$ & 127 F-I \\
\hline PI 437151 & TAN & $23 \mathrm{~F}-\mathrm{L}$ & $180 \mathrm{~A}-\mathrm{H}$ \\
\hline PI 548463 & TAN & $22 \mathrm{I}-\mathrm{L}$ & $139 \mathrm{~F}-\mathrm{I}$ \\
\hline PI 549017 & TAN & $22 \mathrm{I}-\mathrm{L}$ & $153 \mathrm{DH}$ \\
\hline PI 561377 & TAN $^{v}$ & $22 \mathrm{~J}-\mathrm{L}$ & $139 \mathrm{~F}-\mathrm{I}$ \\
\hline PI 594538A (Rpplb) & RB & $22 \mathrm{~K}-\mathrm{L}$ & $38 \mathrm{~J}$ \\
\hline PI 561356 & $\mathrm{RB}^{\mathrm{z}}$ & $21 \mathrm{~L}$ & $20 \mathrm{~J}$ \\
\hline
\end{tabular}

${ }^{\mathrm{r}}$ Means followed by the same letter within a column are not significantly different $(P \leq 0.05)$.

${ }^{\mathrm{s}} \mathrm{RB}=$ reddish-brown and $\mathrm{TAN}=$ tan-colored lesions.

${ }^{t}$ Severity was assessed on a scale from 1 to 5 based on percentage of leaf area affected, where $1=$ no visible lesions, $2=0.1$ to $2.5 \%$ leaf area affected, $3=2.6$ to $10 \%$ of leaf area affected, $4=10.1$ to $30 \%$ of leaf area affected, and $5=$ over $30 \%$ of leaf area affected. AUDPC values were calculated based on five assessment dates (25).

"Number of sporulating uredinia combined from two 1-cm-diameter circles was used to calculate AUSUPC values were based on five assessment dates (25).

${ }^{v}$ Reactions with BZ01-1 and PG01-2 were mixed.

${ }^{w}$ Seven of eight plants of PI 084674 produced TAN lesions when inoculated with ZM01-1, with a single plant producing RB lesions; the data from these RB plants were not used in the analysis.

${ }^{x}$ Reactions with BZ01-1 were mixed.

y Reactions with PG01-2 were mixed.

${ }^{\mathrm{z}}$ Six of eight plants of PI 561356 produced RB lesions when inoculated with TH01-1; the remaining two plants produced TAN lesions, the data from these two TAN plants were not used in the analysis. fered $(P \leq 0.05)$ from TH01-1 (142) and BZ01-1 (138) isolates. The AUSUPC value among the accessions ranged from 20 to 241 (Table 1). Williams had one of the highest values, with eight accessions having lower $(P \leq 0.05)$ values than Williams. Of the known sources of single-gene resistance, only PI 230970 (Rpp2), PI 459025B (Rpp4), and PI 594538A (Rpplb) had lower $(P \leq 0.05)$ AUSUPC values than Williams. PI 594538A and PI 561356, both with RB lesions, had the lowest $(P \leq 0.05)$ AUSUPC values.

Number of uredinia per lesion and uredinial diameter. There was a significant $(P<0.05)$ interaction between isolates and accessions (Table 2). Explaining the interaction (4 isolates by 34 accessions or 132 mean values) was complex; therefore, a second analysis was done separating the data based on reaction type. In the analysis of the accessions producing an RB reaction type, differences in number of uredinia were significant $(P \leq$ $0.05)$ among isolates, among accessions, and for their interaction. For accessions producing TAN lesions, there were significant $(P$ $<0.05$ ) differences among isolates and accessions (Table 2). For uredinial diameter in RB reactions, there were significant $(P<$ 0.01 ) differences among accessions. When accessions producing TAN lesions only were analyzed, there were significant differences among isolates $(P<0.05)$ and accessions $(P<0.01)$ (Table 2).

Table 2. Analysis of variance of area under disease progress curve (AUDPC), area under sporulating uredinia progress curve (AUSUPC), number of uredinia per lesion (Uredinia), and uredinial diameters (Diameter) for 34 soybean accessions inoculated with four isolates of Phakopsora pachyrhizi under greenhouse conditions

\begin{tabular}{|c|c|c|c|c|}
\hline Source $^{\mathrm{z}}$ & df & $\begin{array}{l}\text { Denominator } \\
\text { df }\end{array}$ & $F$ ratio & $P>F$ \\
\hline \multicolumn{5}{|l|}{ AUDPC } \\
\hline Isolate & 3 & 9 & 16.3 & 0.0005 \\
\hline Replication & 3 & 9 & 1.5 & 0.2803 \\
\hline Accession & 33 & 932 & 3.0 & $<0.0001$ \\
\hline Isolate-accession & 99 & 932 & 1.2 & 0.1385 \\
\hline \multicolumn{5}{|l|}{ AUSUPC } \\
\hline Isolate & 3 & 9 & 11.5 & 0.0019 \\
\hline Replication & 3 & 9 & 0.7 & 0.5908 \\
\hline Accession & 33 & 930 & 4.0 & $<0.0001$ \\
\hline Isolate-accession & 99 & 930 & 1.2 & 0.0739 \\
\hline \multicolumn{5}{|l|}{ Uredinia (all) } \\
\hline Isolate & 3 & 9 & 4.4 & 0.0358 \\
\hline Replication & 3 & 9 & 0.6 & 0.6432 \\
\hline Accession & 33 & 871 & 10.2 & $<0.0001$ \\
\hline Isolate-accession & 99 & 871 & 1.3 & 0.0271 \\
\hline \multicolumn{5}{|l|}{ Diameter (all) } \\
\hline Isolate & 3 & 9 & 6.0 & 0.0155 \\
\hline Replication & 3 & 9 & 0.3 & 0.7969 \\
\hline Accession & 33 & 871 & 8.3 & $<0.0001$ \\
\hline Isolate-accession & 99 & 871 & 1.3 & 0.0242 \\
\hline \multicolumn{5}{|l|}{ Uredinia (RB) } \\
\hline Isolate & 3 & 7 & 6.3 & 0.0190 \\
\hline Replication & 3 & 8 & 6.9 & 0.0146 \\
\hline Accession & 5 & 146 & 12.0 & $<0.0001$ \\
\hline Isolate-accession & 15 & 146 & 2.3 & 0.0065 \\
\hline \multicolumn{5}{|l|}{ Diameter (RB) } \\
\hline Isolate & 3 & 9 & 3.9 & 0.0452 \\
\hline Replication & 3 & 9 & 4.2 & 0.0388 \\
\hline Accession & 5 & 146 & 8.1 & $<0.0001$ \\
\hline Isolate-accession & 15 & 146 & 1.5 & 0.1063 \\
\hline \multicolumn{5}{|l|}{ Uredinia (TAN) } \\
\hline Isolate & 3 & 9 & 3.8 & 0.0502 \\
\hline Replication & 3 & 9 & 0.9 & 0.4566 \\
\hline Accession & 27 & 714 & 2.2 & $<0.0004$ \\
\hline Isolate-accession & 81 & 714 & 1.2 & 0.1343 \\
\hline \multicolumn{5}{|l|}{ Diameter (TAN) } \\
\hline Isolate & 3 & 9 & 6.1 & 0.0144 \\
\hline Replication & 3 & 9 & 0.3 & 0.8184 \\
\hline Accession & 27 & 146 & 1.8 & $<0.0072$ \\
\hline Isolate-accession & 81 & 146 & 1.3 & 0.0623 \\
\hline
\end{tabular}

${ }_{\mathrm{z}}$ All $=$ all accessions, $\mathrm{RB}=$ accessions producing red-brown lesions, and TAN $=$ accessions producing tan-colored lesions. 
The average number of uredinia per lesion ranged from 1.3 to 7.0 for all accessions (Table 3). In total, 3 accessions-PI 561356, PI 230970 (Rpp2), and PI 594538A (Rpplb) - produced fewer uredinia per lesion than Williams, while 17 accessions produced more uredinia per lesion than Williams $(P \leq 0.05)$. Of the known sources of single-gene resistance, only PI 230970 (Rpp2) and PI 594538A (Rpplb) produced fewer uredinia per lesion, and PI 200492 (Rppl) produced more uredinia per lesion than Williams $(P=0.05)$.

The diameter of uredinia ranged from 101 to $152 \mu \mathrm{m}$ for all accessions (Table 3). In total, 3 accessions-PI 561356, PI 230970 (Rpp2), and PI 594538A (Rpplb)-produced smaller uredinial diameters than Williams $(131 \mu \mathrm{m})$ and all the other accessions, while 16 accessions produced larger uredinial diameters than Williams $(P \leq 0.05)$. Of the known sources of single-gene resistance, PI 230970 (Rpp2) and PI 594538A (Rpplb) produced smaller uredinia than Williams $(P \leq 0.05)$.

When accessions were separated by reaction type and then analyzed, only the number of uredinia per lesion had a significant interaction effect $(P<0.01$; Table 2$)$. All accessions except those with known single genes had a differential response to the isolates (Table 4). PI 230970 (Rpp2) and PI 594538A (Rpplb) had fewer uredinia than PI 459025B (Rpp4) for all the isolates $(P \leq 0.05)$.

Correlations. Of the variables, AUDPC and the AUSUPC were correlated $(r=0.66, P<0.001)$, as were the number of uredinia per lesion and uredinial diameter $(r=0.62, P<0.001)$. There was a

Table 3. Mean number of uredinia per lesion and diameter of uredinia recorded on sampled leaflets that were cleared and stained on 34 soybean accessions inoculated with four Phakopsora pachyrhizi isolates 17 days before sampling under greenhouse conditions ${ }^{\mathrm{w}}$

\begin{tabular}{|c|c|c|}
\hline Accession $^{x}$ & $\begin{array}{l}\text { Mean no. of uredinia } \\
\text { per lesion }\end{array}$ & $\begin{array}{c}\text { Mean diameter } \\
\text { of uredinia }(\mu \mathrm{m})^{\mathrm{z}}\end{array}$ \\
\hline PI 417560 & $7.0 \mathrm{~A}$ & 145 A-E \\
\hline PI 206258 & $6.9 \mathrm{~A}-\mathrm{B}$ & $147 \mathrm{~A}-\mathrm{D}$ \\
\hline PI 084674 & $6.7 \mathrm{~A}-\mathrm{C}$ & $150 \mathrm{~A}-\mathrm{B}$ \\
\hline PI 424456 & $6.7 \mathrm{~A}-\mathrm{D}$ & $152 \mathrm{~A}$ \\
\hline PI 417012 & $6.6 \mathrm{~A}-\mathrm{E}$ & 144 A-E \\
\hline PI 548484 & $6.3 \mathrm{~A}-\mathrm{F}$ & 143 A-E \\
\hline PI 164885 & $6.2 \mathrm{~A}-\mathrm{G}$ & $140 \mathrm{~B}-\mathrm{G}$ \\
\hline PI 189402 & $6.0 \mathrm{~A}-\mathrm{H}$ & $134 \mathrm{~F}-\mathrm{H}$ \\
\hline PI 427241 & $5.9 \mathrm{~A}-\mathrm{H}$ & $142 \mathrm{~A}-\mathrm{F}$ \\
\hline PI 437151 & $5.9 \mathrm{~A}-\mathrm{H}$ & $147 \mathrm{~A}-\mathrm{D}$ \\
\hline PI $200492(R p p 1)$ & $5.9 \mathrm{~A}-\mathrm{H}$ & $140 \mathrm{~B}-\mathrm{G}$ \\
\hline PI 438480 & $5.8 \mathrm{~A}-\mathrm{H}$ & $142 \mathrm{~A}-\mathrm{G}$ \\
\hline PI 507716 & $5.8 \mathrm{~A}-\mathrm{H}$ & 143 A-E \\
\hline PI 561287B & $5.8 \mathrm{~B}-\mathrm{H}$ & $149 \mathrm{~A}-\mathrm{C}$ \\
\hline PI 196528 & $5.7 \mathrm{C}-\mathrm{H}$ & $147 \mathrm{~A}-\mathrm{D}$ \\
\hline PI 561377 & $5.7 \mathrm{C}-\mathrm{H}$ & 149 A-D \\
\hline PI 548463 & $5.5 \mathrm{D}-\mathrm{H}$ & $141 \mathrm{~B}-\mathrm{G}$ \\
\hline PI 467323A & $5.5 \mathrm{D}-\mathrm{J}$ & $145 \mathrm{~A}-\mathrm{E}$ \\
\hline PI 549017 & $5.4 \mathrm{E}-\mathrm{J}$ & $145 \mathrm{~A}-\mathrm{E}$ \\
\hline PI 091144 & $5.3 \mathrm{E}-\mathrm{J}$ & 144 A-E \\
\hline PI 437241 & $5.3 \mathrm{E}-\mathrm{J}$ & $134 \mathrm{E}-\mathrm{H}$ \\
\hline PI 196529 & $5.3 \mathrm{E}-\mathrm{J}$ & 144 A-E \\
\hline PI 547875 (Rppl) & $5.3 \mathrm{E}-\mathrm{J}$ & $141 \mathrm{~A}-\mathrm{G}$ \\
\hline PI 084668 & $5.2 \mathrm{E}-\mathrm{J}$ & $138 \mathrm{C}-\mathrm{G}$ \\
\hline G 7955 (Rpp3) & $5.1 \mathrm{~F}-\mathrm{J}$ & $138 \mathrm{D}-\mathrm{G}$ \\
\hline PI 508269 & $4.9 \mathrm{G}-\mathrm{K}$ & $139 \mathrm{~B}-\mathrm{G}$ \\
\hline PI 417089A & $4.8 \mathrm{H}-\mathrm{K}$ & $141 \mathrm{~B}-\mathrm{G}$ \\
\hline PI 081765 & $4.8 \mathrm{I}-\mathrm{K}$ & $138 \mathrm{E}-\mathrm{H}$ \\
\hline Williams & $4.6 \mathrm{~J}-\mathrm{L}$ & $131 \mathrm{G}-\mathrm{H}$ \\
\hline PI 459025B (Rpp4) & $3.8 \mathrm{~K}-\mathrm{L}$ & $126 \mathrm{H}$ \\
\hline PI 423972 & $3.5 \mathrm{~L}-\mathrm{M}$ & $131 \mathrm{~F}-\mathrm{H}$ \\
\hline PI 561356 & $2.4 \mathrm{M}-\mathrm{N}$ & $101 \mathrm{~J}$ \\
\hline PI 230970 (Rpp2) & $1.8 \mathrm{~N}$ & $115 \mathrm{I}$ \\
\hline PI 594538A (Rpplb) & $1.3 \mathrm{~N}$ & $106 \mathrm{I}-\mathrm{J}$ \\
\hline
\end{tabular}

${ }^{\mathrm{w}}$ Means followed by the same letter within a column are not significantly different $(P \leq 0.05)$.

${ }^{x} \mathrm{PI}=$ plant introduction.

${ }^{y}$ Mean number of uredinia per lesion was determined from 25 lesions from two replicates for each accession from the first run of the experiment.

${ }^{\mathrm{z}}$ Mean uredinia diameter was determined from 25 isolated uredinia from two replicates for each accession from the first run of the experiment. significant but weak correlation of AUSUPC to the number of uredinia per lesion $(r=0.1, P<0.02)$ and uredinial diameter $(r=$ $0.1, P<0.02)$.

Sporulation within RB lesions. Based on the analysis of variance, there was no interaction between isolate and accession. Only accession differed for relative level of sporulation, and this ranged from 6 to $58 \%$ over all isolates compared with Williams. PI 459025B had the highest relative sporulation (58\%), followed by PI 423972 (46\%), PI 081765 (44\%), and PI 230970 (36\%); PI 594538A (9\%) and PI $561356(6 \%)$ had the lowest.

\section{Discussion}

Resistance in soybean to $P$. pachyrhizi is characterized by either $\mathrm{RB}$ lesions or an immune response. The RB type of resistance is incomplete, as shown by our data on sporulating uredinia within lesions. Susceptibility, on the other hand, is exemplified by TAN lesions, and can be expressed in gradations that we refer to as partial resistance when sporulation levels are equal to or lower than those found in the RB lesions. In this study, six accessions produced RB lesions to all four isolates and, for those accessions, there was an interaction among isolates and accessions for the number of uredinia per lesion, indicating a differential response for this variable. Nineteen accessions produced TAN lesions and there was no differential response among the isolates for any trait, indicating a nonspecific response. This study characterized and defined rust reaction in 34 accessions based on lesion type and sporulation, and distinguished incomplete from partial resistance in the soybean- $P$. pachyrhizi interaction.

Resistance in soybean to $P$. pachyrhizi was first reported in the 1960 s and 1970s and, later, four major resistance genes were reported to confer specific resistance (7). These genes conferred either an IR or the more common RB lesion response. Susceptibility, on the other hand, was recognized by the formation of TAN lesions and was, by far, the most common reaction type (2). To date, the IR has been conferred only by the Rppl gene, originating in soybean accession PI 200492. The immunity is expressed in response to only a few $P$. pachyrhizi isolates, none of which were

Table 4. Mean number of uredinia per lesion on sampled leaflets from six soybean accessions that produced red-brown lesions 17 days after inoculation with four isolates of Phakopsora pachyrhizi under greenhouse conditions

\begin{tabular}{llc}
\hline Accessions $^{\mathbf{x}}$ & Isolates $^{\mathbf{y}}$ & Mean no. of uredinia per lesion \\
\hline PI 081765 & BZ01-1 & $6.8 \mathrm{~A}$ \\
PI 081765 & PG01-2 & $6.4 \mathrm{~A}-\mathrm{B}$ \\
PI 459025B $($ Rpp4 $)$ & ZM01-1 & $4.6 \mathrm{~B}-\mathrm{C}$ \\
PI 423972 & PG01-2 & $4.6 \mathrm{~B}-\mathrm{C}$ \\
PI 423972 & BZ01-1 & $4.3 \mathrm{C}$ \\
PI 459025B $($ Rpp4 $)$ & BZ01-1 & $4.0 \mathrm{C}-\mathrm{D}$ \\
PI 561356 & TH01-1 & $3.9 \mathrm{C}-\mathrm{E}$ \\
PI 459025B $(R p p 4)$ & PG01-2 & $3.7 \mathrm{C}-\mathrm{F}$ \\
PI 423972 & ZM01-1 & $3.5 \mathrm{C}-\mathrm{G}$ \\
PI 081765 & TH01-1 & $3.3 \mathrm{C}-\mathrm{G}$ \\
PI 081765 & ZM01-1 & $2.9 \mathrm{C}-\mathrm{H}$ \\
PI 459025B $(R p p 4)$ & TH01-1 & $2.8 \mathrm{C}-\mathrm{H}$ \\
PI 561356 & PG01-2 & $2.4 \mathrm{D}-\mathrm{I}$ \\
PI 594538A $(R p p 1 b)$ & TH01-1 & $2.2 \mathrm{D}-\mathrm{I}$ \\
PI 230970 $(R p p 2)$ & BZ01-1 & $2.1 \mathrm{D}-\mathrm{I}$ \\
PI 230970 $(R p p 2)$ & TH01-1 & $1.9 \mathrm{E}-\mathrm{I}$ \\
PI 230970 $(R p p 2)$ & ZM01-1 & $1.8 \mathrm{~F}-\mathrm{I}$ \\
PI 423972 & TH01-1 & $1.8 \mathrm{E}-\mathrm{I}$ \\
PI 561356 & BZ01-1 & $1.8 \mathrm{~F}-\mathrm{I}$ \\
PI 594538A $(R p p 1 b)$ & PG01-2 & $1.8 \mathrm{E}-\mathrm{I}$ \\
PI 561356 & ZM01-1 & $1.6 \mathrm{G}-\mathrm{I}$ \\
PI 230970 $(R p p 2)$ & PG01-2 & $1.3 \mathrm{H}-\mathrm{I}$ \\
PI 594538A $(R p p 1 b)$ & BZ01-1 & $1.2 \mathrm{H}-\mathrm{I}$ \\
PI 594538A $(R p p 1 b)$ & ZM01-1 & $0.8 \mathrm{I}$ \\
\hline
\end{tabular}

x $\mathrm{PI}=$ plant introduction.

y Brazil 01-1 (BZ01-1), Paraguay 01-2 (PG01-2), Thailand 01-1 (TH01-1), and Zimbabwe 01-1 (ZM01-1).

${ }^{\mathrm{z}}$ Means followed by the same letter within a column are not significantly different $(P \leq 0.05)$. 
used in our study. Furthermore, none of the soybean accessions used in our study produced an IR to any of the four isolates tested. Variation in lesion color has previously been reported elsewhere $(1,27,28)$. The inheritance of these other color reaction types has not been determined.

Bromfield (2) described variations of the RB reaction type that included incrementally increasing levels of sporulation. We observed differences in all the variables measured on accessions that produced RB lesions, but they were not consistent. For example, PI 081765 and PI 423972 were not different from Williams in the traits measured, whereas PI 230970, PI 561356, and PI 594538A were consistently lower and considered to have incomplete resistance. Effectiveness of pathotype-specific resistance genes, complete or incomplete, is often short-lived, especially when deployed against obligate pathogens with potentially high virulence variability, such as P. pachyrhizi. The resistance in PI 200492 (Rppl) and PI 230970 (Rpp2) was ineffective in Asia soon after identification and incorporation into breeding programs (7). The effectiveness of PI 200492 (Rppl) and PI 462312 (Rpp3) rapidly declined and the resistance was considered ineffective 2 years after soybean rust was found in Brazil (31), whereas the resistance in both PI 230970 (Rpp2) and PI 459025 (Rpp4) have remained effective $(6,26)$. Durability of these specific genes may vary by geographic region and may be more useful if stacked in various combinations.

Rust severity in our study was not associated with lesion type. For example, among those accessions that had RB lesions, PI 561356 and PI 594538A tended to have lower severity ratings than PI 230970, PI 423972, and PI 459025B, which were among the accessions with the highest severity ratings. Accessions that had TAN lesions and low severities (e.g., PI 548463, PI 548484, and PI 549017) produced uredinia that were similar in diameter and number per lesion to those on Williams, indicating the lack of relationship between disease severity and fungal reproduction.

For soybean rust, reaction types RB and IR were considered the only expression of resistance. However, slow rusting, defined as quantitative resistance (12) or, in our definition, partial resistance, also occurs in the soybean- $P$. pachyrhizi interaction based on differences we found among the accessions with TAN lesions. This has been mentioned in other research on variation in the number of uredinia within TAN lesions on a limited set of accessions $(1,2,30)$. This trait also was found to be important in the field, where the number of uredinia per leaf area was shown to be inversely correlated with yield (29). Based on this relationship with soybean yield, uredinial counts are an important trait to consider when evaluating partial resistance in soybean germplasm. This trait, based on our data from inoculated soybean plants in greenhouse studies, also provided greater separation of genotypes than severity or uredinial diameter and, therefore, appears to be a good measurement of partial resistance.

In summary, knowledge of virulence in $P$. pachyrhizi populations will be essential for prioritizing intelligent deployment of specific resistance genes in different geographic regions and over time. A common set of soybean differentials and universally accepted methods to measure virulence may help with the deployment of resistance genes and with determining whether new rust resistance sources possess unique resistance genes. In addition, more effort is needed to determine the possibility and effectiveness of breeding for partial resistance. Although traits related to partial resistance have been identified, their utilization in breeding programs and deployment in commercial production may be challenging.

\section{Acknowledgments}

This research was supported by the United Soybean Board as Projects 2229, 3217, 4217, and 4235, and supports the goals of the USDA National Strategic Plan for the Coordination and Integration of Soybean Rust Research. We thank R. Nelson and the staff at the USDA Soybean Germplasm Collection Center at Urbana, IL for providing soybean seed used in this study; T. Herman and T. Lynch for organizing the sets of seed sent to the FDWSRU; C. Austin, J. Bowers, S. Diepold, and C. Stone for their technical assistance with the seedling valuations; H. Tipton, N. Hoff, and T. Hancock for the histological evaluations at the FDWSRU; and C. B. Hill for his critical review of the manuscript.

\section{Literature Cited}

1. Bonde, M. R., Nester, S. E., Austin, C. N., Stone, C. L., Frederick, R. D., Hartman, G. L., and Miles, M. R. 2006. Evaluation of virulence of Phakopsora pachyrhizi and P. meibomiae isolates. Plant Dis. 90:708-716.

2. Bromfield, K. R. 1984. Soybean Rust, Monograph No. 11. American Phytopathological Society, St. Paul, MN.

3. Bromfield, K. R., and Hartwig, E. E. 1980. Resistance to soybean rust and mode of inheritance. Crop Sci. 20:254-255.

4. Calvo, E. S., Kiihl, R. A. S., Garcia, A., Harada, A., and Hiromoto, D. M 2008. Two major recessive soybean genes conferring soybean rust resistance. Crop Sci. 48:1350-1354.

5. Chakraborty, N., Curley, J., Frederick, R. D., Hyten, D. L., Nelson, R. L., Hartman, G. L., and Diers, B. W. 2009. Mapping and confirmation of a new allele at Rppl from soybean PI 594538A conferring RB lesion-type resistance to soybean rust. Crop Sci. 49:783-790.

6. Garcia, A., Calvo, E. S., Kiihl, R. A. D., Harada, A., Hiromoto, D. M., and Vieira, L. G. E. 2008. Molecular mapping of soybean rust (Phakopsora pachyrhizi) resistance genes: discovery of a novel locus and alleles. Theor. Appl. Genet. 117:545-553.

7. Hartman, G. L., Miles, M. R., and Frederick, R. D. 2005. Breeding for resistance to soybean rust. Plant Dis. 89:664-666.

8. Hartman, G. L., Wang, T. C., and Tschanz, A. T. 1991. Soybean rust development and the quantitative relationship between rust severity and soybean yield. Plant Dis. 75:596-600.

9. Hartwig, E. E. 1986. Identification of a fourth major gene conferring resistance to soybean rust. Crop Sci. 26:1135-1136.

10. Hartwig, E. E., and Bromfield, K. R. 1983. Relationship among three genes conferring specific resistance to rust in soybeans. Crop Sci. 23:237-239.

11. Hyten, D. L., Hartman, G. L., Nelson, R. L., Frederick, R. D., Concibido, V. C., and Cregan, P. B. 2007. Map location of the Rppl locus that confers resistance to Phakopsora pachyrhizi (soybean rust) in soybean. Crop Sci. 47:837-838.

12. Leonard, K. J. 2002. Oat lines with effective adult plant resistance to crown rust. Plant Dis. 86:593-598.

13. Levy, C. 2005. Epidemiology and chemical control of soybean rust in Southern Africa. Plant Dis. 89:669-774.

14. Marchetti, M. A., Uecker, F. A., and Bromfield, K. R. 1975. Uredial development of Phakopsora pachyrhizi in soybeans. Phytopathology 65:822-823.

15. McLean, R. J., and Byth, D. E. 1980. Inheritance of resistance to rust (Phakopsora pachyrhizi) in soybeans. Aust. J. Agric. Res. 31:951-956.

16. Melching, J. S., Bromfield, K. R., and Kingsolver, C. H. 1983. The plant pathogen containment facility at Frederick, Maryland. Plant Dis. 67:717-722.

17. Miles, M. R., Frederick, R. D., and Hartman, G. L. 2006. Evaluation of soybean germplasm for resistance to Phakopsora pachyrhizi. Plant Health Progress.

18. Miles, M. R., Hartman, G. L., and Frederick, R. D. 2003. Soybean rust: is the U.S. soybean crop at risk? In: APSnet feature. American Phytopathological Society, St. Paul, MN

19. Miles, M. R., Levy, C., Morel, W., Mueller, T., Steinlage, T., vanRij, N., Frederick, R. D., and Hartman, G. L. 2007. International fungicide efficacy trials for the management of soybean rust. Plant Dis. 91:1450-1458.

20. Mueller, T. A., Miles, M. R., Morel, W., Marios, J. J., Wright, D. L., Kemerait, R. C., Levy, C., and Hartman, G. L. 2009. Effect of fungicide and timing of application on soybean rust severity and yield. Plant Dis. 93:243-248.

21. Parlevliet, J. E. 1979. Components of resistance that reduce the rate of epidemic development. Annu. Rev. Phytopathol. 17:203-222.

22. Paul, C., and Hartman, G. L. 2009. Sources of soybean rust resistance challenged with single-spored isolates of Phakopsora pachyrhizi collected from the USA. Crop Sci. 49:1781-1785

23. Pham, T. A., Miles, M. R., Frederick, R. D., Hill, C. B., and Hartman, G. L. 2009. Differential responses of resistant soybean entries to isolates of Phakopsora pachyrhizi. Plant Dis. 93:224-228.

24. Ribeiro Do Vale, F. X., Parlevliet, J. E., and Zambolim, L. 2001. Concepts in plant disease resistance. Fitopatol. Bras. 26:577-589.

25. Shaner, G., and Finney, R. E. 1977. The effect of nitrogen fertilization on the expression of slow-mildewing resistance in Knox wheat. Phytopathology 67:1051-1056.

26. Silva, D., Yamanaka, N., Brogin, R., Arias, C., Nepomuceno, A., Di Mauro, A., Pereira, S., Nogueira, L., Passianotto, A., and Abdelnoor, R. 2008. Molecular mapping of two loci that confer resistance to Asian rust in soybean. Theor. Appl. Genet. 117:57-63.

27. Slaminko, T. L., Miles, M. R., Frederick, R. D., Bonde, M. R., and Hartman, G. L. 2008. New legume hosts of Phakopsora pachyrhizi based on greenhouse evaluations. Plant Dis. 92:767-771.

28. Slaminko, T. L., Miles, M. R., Marios, J. J., Wright, D. L., and Hartman, G. L. 2008. Hosts of Phakopsora pachyrhizi identified in field evaluations in Florida. Plant Health Prog. doi:10.1094/PHP-2008-1103-01-RS.

29. Wang, T. C., and Hartman, G. L. 1992. Epidemiology of soybean rust and breeding for host resistance. Plant Prot. Bull. 34:109-124.

30. Yeh, C. C., Sinclair, J. B., and Tschanz, A. T. 1982. Phakopsora pachyrhizi: uredial development, uredospore production and factors affecting teliospore formation on soybeans. Aust. J. Agric. Res. 33:25-31.

31. Yorinori, J. T., Paiva, W. M., Frederick, R. D., Costamilan, L. M., Bertagnolli, P. F., Hartman, G. L., Godoy, C. V., and Nunes, J., Jr. 2005. Epidemics of soybean rust (Phakopsora pachyrhizi) in Brazil and Paraguay from 2001 2003. Plant Dis. 89:675-677. 